\title{
ANALISIS IMPLEMENTASI HUKUM EKONOMI ISLAM TERHADAP PRAKTIK JUAL BELI TAHU DAN TEMPE DI DESA LAOK JANG-JANG KANGEAN SUMENEP
}

\author{
Lisriyati \\ Dian Berkah \\ Universitas Muhammadiyah Surabaya \\ Email: 1isaal.imran95@gmail.com
}

\begin{abstract}
To know and tempeh trade that takes place in Laok Jang-Jang Kangean village has been practiced according to the habits that have been in place for a long time in the community. But Islam regulates its people on how to transact well between each other. All the work done should not go out of the way, so that no one feels harmed and no one feels remorse in the future. The problem in this study is how the trading practice system. To know and tempeh in Laok Jang-Jang KangeanSumenep Village and how to Implement Islamic Economic Law in Laok Jang-Jang KangeanSumenep Village. The purpose of this research is to uncover the problem of The Implementation analysis of Islamic Economic Law AgainstTempe To know-selling practices in Laok Jang KangeanSumenep Village.

This research is field reseach that is analyzed using a qualitative descriptive approach. Samples are taken using total sampling that all sellers and buyers know and tempe so that this problem can be presented clearly, the research instruments used are interviews, observations and documentation. Data analysis is done through three steps, namely data reduction, data presentation, and withdrawal of conclusions or verification. Based on research, it is known that the practice of buying and selling toy and tempeh that occurs in the villagers of Laok Jang-Jang KangeanSumenep. it has become a tradition where in trade transactions know and tempe that often only use purchase receipts even some are only by oral.
\end{abstract}

Key Words:Islamic Economic System, Against Buying and Selling Practices 


\section{PENDAHULUAN}

Jual beli tahu tempe di desa laok jang-jang kangean, ialah pembeli mencari calon penjual yang akan menjual tahu dan tempenya. Begitupun sebaliknya terkadang penjual mencari pembeli untuk menjual tahu dan tempe sehingga selanjutnya terjadilah kerja sama yang sesuai dengan kesepakatan bersama. Jika harga sudah dirasa cocok, maka dilanjutkan dengan memriksa langsung kepabrik tahu dan tempe untuk melihat langsung tempe dan tahu tersebut, jika layak dan sesuai dengan keinginan antara penjual dan pembeli, maka dibuatlah perjanjian yang dimana pembayaran akan dilakukan setelah proses pembuatan tahu dan tempe itu selesai, dan dalam perjanjian tersebut harus ada kepastian kapan bisa diambil tahu dan tempe tersebut sehingga dalam transaksi tersebut hanya menggunakan kwitansi bahkan terkadang hanya menggunakan lisan, dan harus diupayakan agar tidak keluar dari ketentuan-ketentuan yang sudah ada dalam hukum islam sehingga dapat memberikan manfaat bagi pihak-pihak yang bersangkutan. Sehingga dalam praktiknya, jual beli harus dikerjakan secara konsekuen agar tidak terjadi saling merugikan serta mendatangkan kemaslahatan, menghindari kemudaratan dan tipu daya.

Sebagai seorang pedagang kita harus tetap jujur dan memperhatikan kehalalan dari barang yang kita jual. Selain itu kita juga memperhatikan bagaimana kualitas barang yang kita jual, apakah mutunya sudah baik ataukah kurang layak untuk kita jual kepada customer. Kualitas suatu barang yang kita jual menjadi tanggung jawab kita sebagai pedagang. Oleh sebab itu, kita harus memberikan penjelasan tentang bagaimana kualitas suatu barang yang kita jual dan berapa kuantitas barang yang kita jual pada customer.
Dalam usaha untuk memenuhi kebutuhan hidup, manusia akan melakukan sesuatu yang kiranya akan memberikan atau menambah penghasilannya demikian juga dengan pengrajin tempe di Desa Laok JangJang Kangean. Sebagian penduduk di Desa Laok Jang-Jang Kangean pekerja sebagai pedagang, sebagian produsen tempe, industri tempe merupakan usaha pokok dan sebagian lainnya industri tempe sebagai usaha sampingan.

Industri tahu dan tempe di Desa Laok Jang-Jang Kangean merupakan usaha kecil di mana status pemiliknya yaitu usaha milik sendiri sehingga dapat di kategorikan pada industri kecil.

Karena sebagian penduduk di Desa Laok Jang-Jang Kangean bekerja sebagai pedagang, sebagian produsen tempe, industri tempe merupakan usaha pokok usaha sampingan, sehingga yang saya temui atau saya lihat di lapangan mengenai praktik jual beli tahu dan tempe di desa laok jang-jang kangean sumenep. dimana sistem praktik jual belinya pembeli mencari calon penjual yang akan menjual tahu dan tempenya. begitupun sebaliknya terkadang penjaul mencari pembeli untuk menjual tahu dan tempe sehingga terjadilah kerja sama yg sesuai dengan kesepakatan bersama.jika harga sudah dirasa cocok maka dilanjutkan dengan memeriksa langsung kepabriknya tahu dan tempe untuk melihat langsung tempe dan tahu tersebut, jika dirasa layak dan sesuai dengan keinginan antara penjual dan pembeli, maka dibuatlah perjanjian dimana pembayaran akan dilakukan setelah proses pembuatan tahu dan tempe itu selesai, sehingga dalam perjanjian tersebut harus ada kepastian kapan bisa diambil tahu dan tempe tersebut hingga dalam transaksi tersebut hanya menggunakan kwitansi bahkan terkadang hanya menggunakan lisan. 
Praktik jual beli tempe disini agak berbeda, tempe yang diperjual belikan adalah tempe yang berbahan dasar campuran yang terjadi di Desa Laok Jang-Jang Kangean. Tempe berbahan dasar campuran tersebut sudah berjalan hingga usia 3 tahun lebih lamanya. Dikarenakan kedelai yang menipis di Indonesia dan akhir di impor dari luar negeri, membuat kedelai menjadi mahal. Saat itu juga para penjual atau pembuat tempe melakukan formula baru demi menghidupi keluarganya yaitu dengan cara mencampurkan kedelai dengan campuran bahan pokok lainnya selain kedelai.

Berdasarkan penjelasan dan uraian diatas maka peneliti mengkaji lebih jauh melalui penelitian tentang Analisis Implementasi Hukum Ekonomi Islam Terhadap Praktek Jual Beli Tahu Tempe Di Desa Laok Jang-Jang Kangean Sumenep".

\section{LANDASAN TEORI}

\section{Pengertian Implementasi}

Implementasi merupakaan tahap proses atau pelaksanaan yang dilakukan untuk mencapai tujuan yang telah ditetapkan dalam keputusan kebijakan. Model manajemen implementasi menurut Nugroho menggambarkan pelaksanaan atau implementasi kebijakan dalam konteks manajemen berada dalam kerangka oganizing-leading-controlling. ${ }^{1} \quad$ Jadi ketika kebijakan sudah dibuat, maka tugas selanjutnya adalah mengorganisasikan, melaksanakan kepemimpinan untuk memimpin pelaksanaan, dan melakukan pengendalian pelaksanaan tersebut. Dalam manajemen implementasi kebijakan dapat disusun melalui (1) Implementasi strategi,

${ }^{1}$ Nugroho, Riant, Public Policy Edisi Revisi. (Jakarta: Elex Media Komputindo. 2009)
(2) pengorganisasian, (3) penggerakkan dan kepemimpinan, (4) pengendalian. ${ }^{2}$ Dengan demikian, dapat disimpulkan bahwa implementasi berkaitan dengan berbagai kegiatan yang diarahkan untuk merealisasikan program, dimana pada posisi ini eksekutif mengatur cara untuk mengorganisir. Seorang eksekutif mampu mengatur secara efektif dan efisien sumber daya, unit-unit dan teknik yang dapat mendukung pelaksanaan program, serta melakukan interpretasi terhadap perencanaan yang telah dibuat, dan petunjuk yang dapat diikuti dengan mudah bagi realisasi program yang dilaksanakan.

\section{Pengertian Jual Beli}

Jual beli atau perdagangan dalam istilah fiqh disebut al-ba'i yang menurut etimologi berarti menjual atau mengganti. Wahbah al-Zuhaily mengartikannya secara bahasa dengan "menukar sesuatu dengan sesuatu yang lain". Kata al-bai'i dalam bahasa Arab terkadang digunakan untuk pengertian lawannya, yaitu kata al-syira' (beli). Dengan demikian, kata al-ba'i berarti jual, tetapi sekaligus juga berarti beli. ${ }^{3}$

$$
\text { Pasal } 1457 \quad \text { KUHPerdata }
$$
menyatakan bahwa jual beli adalah suatu perjanjian dengan mana pihak yang satu mengikatkan dirinya untuk menyerahkan suatu kebendaan dan pihak yang lain untuk membayar harga yang telah dijanjikan. Dari pengertian yang dinyatakan di dalam Pasal 1457 KUHPerdata maka persetujuan jual beli sekaligus membebankan 2 (dua) kewajiban, yakni :

a. Kewajiban pihak penjual menyerahkan barang yang dijual kepada pembeli, dan

\footnotetext{
2 Stewart,J.J, Hedge, D. M.,\& Lester, J. P, Public policy: An evolutionary approach. Boston: Thomson Wordsworth.,2008

${ }^{3}$ Abdul Rahman Ghazaly, Figh Muamalat (Jakarta: Kencana Prenada Media Group.2010)h. 46
} 
b. Kewajiban pihak pembeli membayar harga barang yang dibeli kepada penjual. ${ }^{4}$

menurut Sayyid

Sabiq mendefinisikan jual beli yaitu:

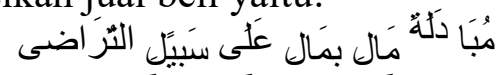

"saling menukar harta dengan harta atas dasar suka sama suka"

Menurut Sayyid Sabiq dijelaskan bahwa pengertian jual beli secara istilah adalah penukaran harta tertentu dengan harta lain, seperti memindahkan hak milik dengan hak milik lain berdasarkan persetujuan dan perhitungan materi. ${ }^{5}$

\section{Hak Kewajiban Penjual Dan Pembeli}

Salim H.S. mengatakan ada beberapa kewajiban penjual, yaitu :6

a. Menyatakan dengan tegas tentang perjanjian jual beli tersebut;

b. Menyerahkan barang, adalah suatu pemindahan barang yang telah dijual ke dalam kekuasaan dan kepunyaan si pembeli. Ada tiga cara melakukan penyerahan barang, yaitu :

1) Penyerahan barang bergerak cukup dengan menyerahkan kekuasaan barang tersebut.

2) Barang tetap dilakukan dengan menggunakan akta transport atau balik nama pada pejabat yang berwenang, dan

3) Barang tak bertubuh dengan cara cessie. Masalah biaya dan tempat penyerahan ditentukan sebagai berikut :

c. Biaya penyerahan barang dipikul oleh si penjual, sedangkan biaya pengambilan dipikul oleh si

${ }^{4}$ M.Yahya Harahap , Segi-segi Hukum Perjanjian, (Alumni, Bandung. 1986)h. 23

${ }^{5}$ Sayyid Sabiq, Fiqih Sunnah, jilid 4, jakarta : pena pundi Aksara, 2006, h.121

${ }^{6}$ Gemala Dewi, , Hukum Perikatan Islam diIndonesia, (Jakarta:Kencana. 2005) pembeli, kecuali diperjanjikan, dan

d. Tempat penyerahan dilakukan ditempat dimana barang yang dijual berada, kecuali diperjanjikan lain :

1) Kewajiban pembeli menanggung dari si penjual adalah dimaksudkan agar penguasaan benda secara aman dan tentram.

2) Wajib mengembalikan kepada si pembeli atau menyuruh mengembalikan oleh orang yang memajukan tuntutan barang tersebut, salah satunya, seperti perhiasan.

3) Wajib menanggung terhadap cacat tersembunyi.

4) Wajib mengembalikan harga pembelian yang diterimanya, jika penjual mengetahui barang yang telah dijual mengandung cacat.

5) Wajib mengembalikan harga pembelian, apabila ia sendiri mengetahui adanya cacat tersebut.

6) Jika barang yang dijual musnah disebabkan adanya cacat tersembunyi, maka kerugian dipikul oleh si penjual dan diwajibkan mengembalikan harga.

7)

\section{Rukun Jual Beli}

Jual beli mempunyai rukun dan syarat yang harus dipenuhi, sehingga jual beli itu dapat dikatakan sah oleh syara'. Dalam menentukan rukun jual beli terdapat perbedaan pendapat ulama Hanafiyah dengan Jumhur Ulama. Rukun jual beli menurut ulama Hanafiyah hanya satu, yaitu ijab dan qabul ijab adalah ungkapan membeli dari pembeli, dan qabul adalah ungkapan menjual dari penjual. Akan 
tetapi, karena unsur kerelaan itu merupakan unsur hati yang sulit untuk dihindra sehingga tidak kelihatan, maka diperlukan indikasi yang menunjukkan kerelaan itu dari kedua belah pihak. ${ }^{7}$ Akan tetapi Jumhur Ulama menyatakan bahwa rukun jual beli itu ada empat, yaitu:

a. Ada orang yang berakad (penjual dan pembeli).

b. Ada sighat (lafal ijab qabul).

c. Ada barang yang dibeli (ma'qud alaih)

d. Ada nilai tukar pengganti barang.

\section{Syarat Jual Beli Menurut Islam}

Syarat-syarat dalam akad jual beli diantarnya, yaitu: ${ }^{8}$

a. Saling rela antara kedua belah pihak, syarat akad ini ialah harus ada kesepakatan terhadap harga dan jenis barang karena jika terjadi perbedaan terhadap harga atau objek yang ditransaksikan diantara keduanya, maka jual belinya akan batal.

b. Pelaku akad adalah orang yang dibolehkan melakukan akad, yaitu orang yang telah baligh, berakal dan mengerti, selain itu tidak sah, kecuali dengan seizin walinya dan kecuali akad yang bernilai rendah.

\section{Hukum Jual Beli}

Dalam kehidupan manusia, jual beli merupakan kebutuhan yang mendasar dan sangat penting. Manusia tidak dapat hidup tanpa adanya kegiatan jual beli, disamping itu juga sebagai sarana tolong menolong antara sesama manusia yang mempunyai landasan kuat dalam Islam.

\footnotetext{
${ }^{7}$ Nasrun Haroen,, fiqh muamalah (Jakarta : Gaya Media Pratama.2007), h 46

${ }^{8}$ Abu Malik Kamal, Shahih Fiqih Sunnah, Muhammad Nashirdhin al-Albani et al. 2008. jilid 5,( Jakarta: Pustaka at-Tazkia.2008), h.27
}

Adapun yang menjadi dasar landasan hukum disyari'atkannya jual beli adalah sebagai berikut:

a. Landasan Al-Qur'an

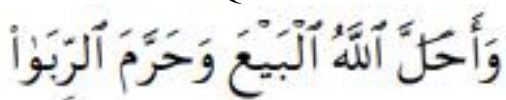

Artinya: "Dan Allah telah menghalalkan jual beli dan mengharamkan riba'. (QS. al-Baqarah ayat 275). ${ }^{9}$

b. Landasan As-Sunnah

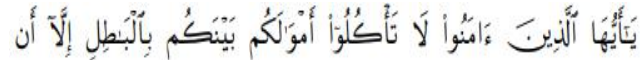

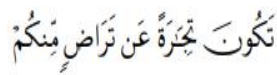

Artinya: ,Dari Rafi'ah bin Rafi' r.a (katanya); sesungguhnya Nabi Muhammad SAW pernah ditanyai, manakah usaha yang paling baik? Beliau menjawab: ialah amal usaha seseorang dengan tangannya sendiri dan semua jual beli yang bersih.' (Riwayat Bazzar dan disahkan oleh Hakim). ${ }^{10}$

c. Landasan Ijmak

Menurut landasan ijmak, para ulama' telah bersepakat bahwa jual beli diperbolehkan dengan alasan manusia tidak akan mampu mencukupi kebutuhan dirinya sendiri, tanpa bantuan orang lain. Dengan demikian, bantuan atau barang milik orang lain yang dibutuhkannya tersebut, harus diganti dengan barang lainnya yang sesuai. ${ }^{11}$

Menurut penulis, dari hadis dan ayat diatas dapat disimpulkan bahwa inti jual beli adalah perjanjian tukar menukat benda atau barang yang mempunyai nilai secara suka rela antara kedua belah pihak, yang satu memberikan benda dan pihak yang lain menerimanya sesuai dengan perjanjian dan ketentuan yang sudah disepakati.

\footnotetext{
${ }^{9}$ Departemen Agama RI, 1985, h. 37

${ }^{10}$ Sayyid al-Imam Muhammad Ibn Ismail al-Kahlani Al-Sanani, Subul Al-Salam Juz III, (Kairo: Dar alKutub al-Ilmiyah.1998)

${ }^{11}$ Rachmat Syafei, Fiqih Muamalah, (Bandung: CV
} Pustaka. 2006)h. 34 


\section{PENELITIAN TERDAHULU}

Penelitian ini dilakukan oleh Wiwin Azizah (2007) dengan judul "Tinjauan Hukum Islam Tentang Jual Beli Tempe Dengan Bahan Dasar Campuran (Studi Pada Pasar Tradisional Sukarame Bandar Lampung)". penelitian tersebut berfokus pada Praktek Jual Beli Tempe dengan Bahan Dasar Campuran Di Pasar Tradisional Sukarame serta bagaimana Tinjauan Hukum Islam Tentang Jual Beli Tempe Dengan Menggunakan Bahan Dasar Campuran.

Penelitian ini dilakukan Rif'an (2008) dengan judul "Analisis Hukum Islam Terhadap Jual Beli Ampas Tahu untuk Pakan Ternak Babi (studi Lapangan di Dusun Tandang, Kelurahan Jomblang, Kecamatan Candisari, Kota Semarang)". Penelitian tersebut berfokus pada praktek jual beli ampas tahuu ntuk pakan ternak babi yang terjadi di dusun Tandang, Kelurahan Jomblan, Kecamatan Candisari, Kota Semarang.

Penelitian yang dilakukan Ely Nurjaliyah (2010) dengan judul " Pandangan Hukum Islam Terhadap Penetapan Harga Dalam Jual Beli di Rumah Makan Prasmanan Pendowo Limo J1. Bima Sakti No. 37 Sapen Yogyakarta". Penelitian tersebut fokus pada penentuan harga pada jual beli makanan yang mengandung unsur ketidak adilan antara pembeli yang satu dengan pembeli yang lainnya, yaitu menetapan harga yang sama dalam porsi makan yang berbeda, khususnya di rumah makan yang mengambil makan sendiri atau disebut juga prasmanan.

\section{METODE PENELITIAN}

Jenis penelitian ini adalah penelitian kualitatif dengan pendekatan studi kasus sehingga dapat mengetahui bagaimana Analisis Implementasi hukum ekonomi syariah terhadap praktik jual beli tahu dan tempe di desa laok jang-jang kangean sumenep yang sebenar-benarnya. Peneliti melihat kepada sistem praktik jual beli. Penelitian di fokuskan pada sistem praktik jual beli tahu tempe di desa laok jang-jang kangean sumenep. Sehingga dari penelitian tersebut peneliti mengetahui tentang penjualan tahu dan tempe di desa laok jang-jang kangean sesuai atau tidak dengan ekonomi islam yang berlaku. Penelitian ini menggunakan metode Triangulasi untuk memeriksa dan menetapkan validitas dengan menganalisa dari perspektif.

Penelitian ini dilaksanakan di desa laok jang-jang kangean sumenep pada bulan 10 Juni - 07 Agustus 2020.

Sumber data penelitian ini diperoleh dari hasil wawancara pemilik pabrik tahu dan tempe di desa laok jang-jang kangean atas nama Sai kemudian Firda sebagai konsumen di desa laok jang-jang kangean

Analisis data dalam penelitian ini dilakukan dengan mereduksi data hasil temuan di lapangan menjadi data-data yang penting dan dibutuhkan dalam penelitian, hasil reduksi data disajikan dalam bentuk teks yang bersifat naratif, dari hasil pemaparan dan penyajian data diambil kesimpulan akhir dari hasil penelitian.

\section{HASIL DAN PEMBAHASAN}

a) Gambaran Umum Desa Laok JangJang Kecamatan Arjasa Kabupaten Sumenep

1. Sejarah Desa

Disini peneliti akan memberikan gambaran keadaan geografis dari desa laok jang-jang Kecamatan Arjasa yang menjadi obyek penelitian. Yaitu Berdasarkan keadaan geografisnya dalam penggunaannya desa Laok jangjang menempati areal seluas 901,21 Ha. 
Dengan banyaknya dusun didesa ini yaitu 9 dusun dengan 12 RT dan 6 RW.

Untuk masyarakat desa Laok JangJang Kangean Sumenep dilihat dari tingkat kesejahteraan masyarakat di desa ini yaitu untuk masyarakat yang menengah kebawah sebesar 312 penduduk, sedangkan masyarakat yang menengah atau sejahtera tingkat 2 sebesar 525, serta masyarakat yang menengah keatas sebesar 85. Sehingga kita disini dapat menyimpulkan bahwa masyarakat desa laok jang-jang rata-rata masyarakatnya bisa dibilang sejahtera.

Meskipun rata-rata dari tingkat ekonomi desa laok jang-jang ini masing-masing desa lebih banyak yang sejahtera dibandingkan warga yang prasejahtera, tetapi secara ekonomi ini juga mempengaruhi tingkat interaksi sosial yang terjadi antar warga yang mana di kecamatan Arjasa sendiri menurut masyarakat di kecamatan ini, untuk warga desa seperti desa Kalinganyar dan Paseraman dalam hal ekonomi masih dikatakan lebih rendah tingkatannya dari pada orang dari bagian barat desa Arjasa seperti laok jang-jang, sehingga orang laok jangjang menilai jika masyarakat desa Kalinganyar ini masih disebut desa yang tertinggal,sehingga interaksi sosialnya juga bisa terjadi dengan memilah-milah pada siapa mereka berinteraksi.

Dari segi Pendidikan merupakan salah satu hal yang sangat penting dalamkehidupan ini. Dengan pendidikan ini kita bisa berproses untukmenuju kerah yang lebih baik, lebih maju, dan berkembang, Apalagidengan pendidikan juga kita akan semakin menambah banyak temantermasuk di kecamatan Arjasa ini. Dari pendidikan juga para remajabisa berinteraksi dengan remaja dari desa lainnya. Banyaknyapenduduk desa laok jang-jang menurut jenjang pendidikan yang diutamatkan.

Untuk kebudayaan sendiri di desa laok jang-jang yaitu disini masihbertahan sampai saat ini yaitu: seni macopat, seni hadraoh, seni dibidang Islam seprti qasidah. ${ }^{12}$ Sedangkan kebudayaan dalam seni didesa Kalinganyar yaitu: Ludruk, kendeng dumik, Pangkak, Hadroh, dan Qasidah. untuk desa Paseraman budayanya yaitu sebagai berikut: kerapan sapi, Macopat, Hadroh, dan ludruk. Biasanya ludruk dari desa Kalinganyar akan diundang ke pesta pernikahan di desa kecamatan Arjasa seperti ke desa Duko, dan Paseraman.

2. Profil usaha tahu dan tempe

Di desa Laok jang-jang kangean sumenep sedikit pengusaha atau pebisnis tahu dan tempe yang semakin hari berkembang karena saingnya tidak begitu banyak. Terbukti hampir seluruh warung di desa laok jang-jang terdapat tahu dan tempe baik berskala besar, menengah maupun kecil.

Disini peneliti mengambil sampel dari usaha tahu dan tempe yang berskala menengah. Oleh karena itu, peneliti mengambil 1 (satu) lokasi yang terbilang luas di desa laok jang-jang. Lokasi usaha tahu dan tempe yang dimaksud ini yaitu para penjual dan produsen tahu dan tempe yang beramatkan di sekitar desa laok jangjang. Usaha tahu dan tempe yang berskala menengah yaitu usaha tahu dan tempe milik bapak Sai

\section{b) Penyajian Data dan Analisis Data 1. Konsep Hukum Islam Dalam Praktik Jual Beli}

Manusia berusaha di bumi dengan cara bekerja, kerja adalah segala kemampuan dan kesungguhan dalam mengolah bumi untuk mencari rizki dari

\footnotetext{
${ }^{12}$ Wawancara dengan pak Sai melalui telfon pada tgl 7 agustus 2020
} 
Allah dalam rangka memenuhi kebutuhan hidupnya. ${ }^{13}$ Pemenuhan kebutuhan hidup manusia disebut juga aktifitas ekonomi.

Aktifitas ekonomi adalah kegiatan seseorang yang berkaitan dengan usaha manusia dalam rangka mewujudkan tujuan, yaitu memenuhi kebutuhan sehari-hari. ${ }^{14}$ Aktifitas ekonomi terdapat tiga hal yang penting yaitu: produksi, distribusi dan konsumsi, aktifitas ekonomi tersebut haruslah berpedoman pada Alqur'an dan Sunnah. Dari aktifitas tersebut yang paling penting adalah produksi, karena produksi merupakan langkah awal dari ketiga aktifitas tersebut, tanpa adanya kegiatan produksi maka tidak aka nada yang dapat didistribusikan, dan kosumen tidak dapat mengkonsi barang.

Produksi tidak akan berjalan tanpa produsen, karena produsen adalah orang atau organisasi yang melakukan aktifitas produksi. Dalam Islam perilaku produsen dan pengaturan proses produksi dari pemilihan barang baku pengolahan dan hasilnya haruslah sesuai dengan syariat Islam. Seseorang produsen muslim tidak semata-mata mencari keuntungan, akan tetapi ia juga harus dapat menghasilkan barang yang bermanfaat dan berkualitas baik, serta memegang nilai-nilai Islam dalam setiap tindakannya. ${ }^{15}$

Jual beli merupakan (perdagangan) dalam konsep Islam yaitu merupakan wasilat al hayat, sarana manusia untuk memenuhi kebutuhan jasadiyah dan ruhiyah agar menusia dapat meningkatkan martabat dan citra dirinya dengan baik sesuai fitrahnya sebagai

\footnotetext{
${ }^{13}$ Yusuf Qardhawi, Peran Nilai dan Moral Dalam Perekonomian Islam, (Jakarta: Robbani Press, 1997, ) h.146.

${ }^{14}$ Hamzah Yakub, 1984,Kode Etik Dagang Menurut Islam, (Bandung: Diponegoro1984), h. 42.

${ }^{15}$ Susilo, Kelompok Kendali Mutu, (Jakarta: Rajawali Pers,2004) h. 24
}

makhluk Allah yang memiliki potensi ketuhanan, sarana mendidik dan melatih jiwa manusia sebagai khalifah dimuka bumi untuk memproduksi khalifahkhalifah yang tangguh dan memiliki kejujuran diri. ${ }^{16} \mathrm{Jual}$ beli merupakan suatu bagian mauamalah yang biasa dialami oleh manusia sebagai sarana berkomunikasi dalam hal ekonomi. Dari pelaksanann jual beli itulah maka apa yang dibutuhkan manusia dapat diperoleh, bahkan dengan jual beli ini pula manusia akan mendapatkan.

Hukum Islam adalah seperangkat peraturan berdasarkan wahyu Allah dan sunnah Rasul tentang tingkah laku manusia mukallaf yang diakui dan di yakini berlaku dan mengikat untuk ummat yang beragama islam . Dalam pengertian lain, Hukum Islam adalah sekumpulan ketetapan hukum kemaslahatan mengenai perbuatan hamba yang terkandung dalam sumber Al-Qurean dan As-sunnah baik ketetapan yang secara langsung ataupun tidak langsung. ${ }^{17}$

Sedangkan dalam Praktek jual beli, hukum islam melarang terhadap penipuan jual beli seperti mengurangi timbangan, untung yang terlalu banyak dan berbagai hal lain yang merusak persaingan bisnis. Bagi orang yang berani melakukan kecurangan akan memperoleh kehinaan kelak di hari kiamat. Perilaku tersebut sering kita jumpai di pasar-pasar tradisioanal, ditoko-toko banyak yang curang melakukan transaksi.Dengan kecurangannya dalam transaksi seperti praktek kebohongan, menjual barang rusak, hal tersebut telah merugikan dan mengecewakan pembeliatas perilaku

\footnotetext{
${ }^{16}$ Muhammad,Aspek Hukum dalam Muamalat,(Yogyakarta: Graha Ilmu,2007)h. 82. ${ }^{17}$ Bunyana Sholihin, Kaidah Hukum Islam dalam Tertib dan Fungsi Legislasi Hukum dan Perundang-undangan,(Yogyakarta : Kreasi Total Media, 2016.)
} 
para pedagang serta merusak persaingan bisnis di dunia pasar. ${ }^{18}$

Sedangkan penjual dalam memuaskan pelanggan, penjual harus melakukan beberapa hal tersebut antara lain, adil dalam menimbang, menunjukan cacat barang yang diperjual belikan, menjauhi sumpah dalam jual beli dan tidak memprktekan apa yang di sebut bai'najasy yaitu memuji atau mengemukakan keunggulan barang pdahal mutunya tidak sebaik yang di promosikan, hal ini juga berarti juga membohongi pembeli. Selain itu juga prinsip coutemer oriented juga memberikan kepada konsumen atas hak khiyar (meneruskan atau membatalkan transaksi) jika ada indikasi penipuan atau merasa dirugikan. Konsep khiyar ini dapat menjadi faktor untuk menguatkan posisi konsumen dimata produsen, sehingga produsen atau perusahaan manapun tidak dapat berbuat semena-mena terhadap pelanggannya.

Untuk itu, suatu perdagangan atau transaksi harus jelas adanya, harus mengikuti ketentuan yang telah diberlakukan, baik itu meliputi rukun dan syarat jual beli agar terhindar dari hal-hal yang dilarang. Seiring dengan berjalannya waktu dan berkembangnya zaman ke arah yang lebih modern, maka transaksi jual beli menjadi beraneka ragam dalam bentuk maupun cara. Meskipun terkadang cara yang dilakukan belum tentu benar dengan apa yang telah ditetapkan oleh syarieeat Islam, salah satunya adalah seperti jual beli tempe. ${ }^{19}$

Dimana Tempe merupakan salah satu produk dari industri yang berbahan baku kedelai. Kedelai merupakan salah satu jenis kacang-kacangan yang mengandung protein nabati yang tinggi,

\footnotetext{
${ }^{18}$ Muhammad, h.93

${ }^{19}$ M. Lies Suprapti, Pembuatan Tempe,(Yogyakarta: Kanisius 2003).,h. 23.
}

sumber lemak, vitamin, dan mineral. Maka dari itu banyak masyarakat khususnya mengolah kedelai menjadi berbagai makanan maupun minuman, yang salah satunya dan paling diminati konsumen adalah tempe. Selain mudah didapat, harga tempe juga terjangkau oleh semua lapisan masyarakat.

\section{c) Implementasi Hukum Ekonomi Islam Terhadap Praktik Jual Beli Tahu Dan Tempe Di Desa Laok Jang-Jang Kangean Sumenep}

Industri tahu dan tempe di Desa Laok Jang-Jang Kangean merupakan usaha kecil di mana status pemiliknya yaitu usaha milik sendiri sehingga dapat di kategorikan pada industri kecil. Pak Sai sudah menjalankan usaha industri tempe di Desa Laok Jang-Jang Kangeanselama 12 tahun. Sebagian penduduk di Desa Laok Jang-Jang Kangean bekerja sebagai pedagang, sebagian produsen tempe, industri tempe merupakan usaha pokok dan sebagian lainnya industri tempe sebagai usaha sampingan.

Pak Sai juga menjelaskan alasan mengapa dibangun industri tempe di Desa Laok Jang-Jang Kangean, dikarenakan dulu dikangean sangat langka, maksudnya tidak ada orang menjual tahu dan tempe, akhirnya saya Punya mayoritas bagaimana orang kangean tidak mengambil tahu dan tempe dari kabupaten sumenep, masalahnya kalau ngambil tahu dan tempe dari sumenep itu jangkanya untuk sampai di kangean itu 3 hari baru sampai kekangean, jadi tahu itukan paling lamanya intinya 5 hari harus bisa di komsumse tidak bisa 1 minggu, jadi alasan pertama saya bagaimana orang kangean itu tidak mengirim tahu dan tempe yang dari kabupaten sumenep. ${ }^{20}$

\footnotetext{
${ }^{20}$ Sai, penjual 08 juni 2020
} 
Praktik jual beli tempe dan tahu disini agak berbeda, tempe yang diperjual belikan adalah tempe yang berbahan dasar campuran yang terjadi di Desa Laok Jang-Jang Kangean Sumenep. Tempe berbahan dasar campuran tersebut sudah berjalan hingga usia 3 tahun lebih lamanya. Dikarenakan kedelai yang menipis di Indonesia dan akhir di impor dari luar negeri, membuat kedelai menjadi mahal. Saat itu juga para penjual atau pembuat tempe melakukan formula baru demi menghidupi keluarganya yaitu dengan cara mencampurkan kedelai dengan campuran bahan pokok lainnya selain kedelai.

Untuk awal kali pejualan tahu dan tempe Pak Sai belum memiliki banyak customer, Pertama kali dulu Pak Sai hanya memiliki pelanggan 5 orang lalu dari 5 tersebut orang akhirnya meningkat mencapai 20 orang. Pertama saya dulu buat tahu dan tempe paling banyak 50kg 1 hari, kalau sekarang buat tahu dan tempe mau mencapai 5 kwintal. ${ }^{21}$

Adapun penuturan Pak Sai sebagai pemilik industri tempe di Desa Laok Jang-Jang Kangean, cara atau sistem jual beli tempe yang biasa dilakukan dulu sistemnya masih mengikuti harga kedelai, soalnya dulukan kedelai masih 4 ribu 3.500 perkilo gram tapi itu dulu, pertama saya buat tahu dan tempe mula $2 \mathrm{x}$ kedelai 4 ribu. Kalau sekarang naik 8.500 ribu sampainya kesini, jadi harga tahu satu petaknya atau kata orang kangean 1 papan, dulu awal buka tahu 1 papan nya harganya 18 ribu. Sekarang 1 papan sudah mencapai 33 ribu.

Jual beli adalah menukar barang dengan barang atau barang dengan uang dengan jelas melepaskan hak milik dari satu kepada yang lain atas dasar

\footnotetext{
${ }^{21}$ Sai, penjual, 09 juni 2020
}

merelakan. Menurut jumhur ulama rukun jual beli adalah:

1. Aqid (pihak yang berakad) adalah adanya penjual dan pembeli

2. Sighat (lafal) adalah adanya ijab dan qabul

3. Ma'qud 'Alaih (barang yang diakadkan) adalah harta yang akan dipindahkan dari tangan seorang yang berakad kepada pihak lain.Menurut ulama Hanafiyah, ma'qud 'alaih harus ada. Tidak boleh akad atas barang-barang yang tidak ada atau dikhawatirkan tidak ada.

Adapun syarat-syarat jual beli sesuai dengan rukun juala beli di atas sebagai berikut:

1. Syarat pelaku akad. Bagi pelaku akad disyaratkan, berakal dan memiliki kemampuan memilih. Jadi akad orang gila, orang mabuk, dan anak kecil tidak bisa dinyatakan sah.

2. Syarat yang terkait dengan ijab dan qabul. Pertama, Pernyataan Qabul sesuai dengan pernyataan Ijab. Maksutnya, penjual menjawab setiap hal yang harus dikatakan dan mengatakannya. Kedua, Ijab Qabul dinyatakan di satu tempat. Maksutnya, kedua pelaku transaksi hadir bersama pada saat transasksi, atau transaksi dilaksanakan di satu tempat dimana pihak yang absen mengetahui terjadinya pernyataan Ijab.

3. Syarat-syarat barang akad yaitu:

a. Barang itu ada atau tidak ada di tempat

b. Suci (halal dan baik)

c. Bermanfaat

d. Mampu diserahkan oleh pelaku akad

e. Mengetahui status barang (kualitas, kuantitas, jenis)

f. Barang tersebut dapat diterima oleh pihak yang melakukan akad 
g. Jelas dan diketahui oleh kedua belah pihak yang melakukan akad

h. Ada nilai tukar pengganti barang.

4. Syarat nilai tukar (harga barang)

a. Harga yang disepakati kedua belah pihak harus jelas jumlahnya.

b. Dapat diserahkan pada saat waktu akad (transaksi).

c. Apabila jual beli itu dilakukan secara barter, maka barang yang dijadikan nilai tukar harus jelas dan bukan barang yang diharamkan oleh syara'.

Adapun juga penuturan Pak Sai sebagai pemilik industri tempe di Desa Laok Jang-Jang Kangean mengenai cara akad yang biasanya dilakukan dalam jual beli tersebut yaitu biasanya penjual mengambilnya 33 ribu untuk yang sekarang. Tapi Pak Sai sebagai pemilik industri tempe mengantar kepelanggan dalam sistem kotak, jadi sistemnya yang jual itu sekarang 75 ribu, jadi keuntungan dalam 1 kotak itu untuk yang penjual mencapai 10 ribu dalam 1 kotak, cara Pak Sai yakni tahu dan tempe di antar terlebih dahulu, kemudian terkait pembayaran dibayarkan di akhir akad.

Praktik jual beli tahu dan tempe di desa Laok Jang-Jang Kangean Sumenep. Dimana sistem praktik jual belinya pembeli mencari calon penjual yang akan menjual tahu dan tempenya. begitupun sebaliknya terkadang penjaul mencari pembeli untuk menjual tahu dan tempe sehingga terjadilah kerja sama yg sesuai dengan kesepakatan bersama, jika harga sudah dirasa cocok maka dilanjutkan dengan memeriksa langsung kepabriknya tahu dan tempe untuk melihat langsung tempe dan tahu tersebut, jika dirasa layak dan sesuai dengan keinginan antara penjual dan pembeli, maka dibuatlah perjanjian dimana pembayaran akan dilakukan setelah proses pembuatan tahu dan tempe itu selesai, sehingga dalam perjanjian tersebut harus ada kepastian kapan bisa diambil tahu dan tempe tersebut hingga dalam transaksi tersebut hanya menggunakan kwitansi bahkan terkadang hanya menggunakan lisan. ${ }^{22}$

Pak Sai sebagai pemilik industri tempe di Desa Laok Jang-Jang Kangean juga menjelaskan bagaimana proses penjualan tempe di Desa Laok JangJang Kangean, bahwasanya Kalau di desa ini klau tempe 1 hari sudah mencapai penjualan 1 juta 1 hari tapi kalau tahu 1 hari sudah memcapai 5 juta 1 hari, diDesa Laok Jang-Jang Kangean juga tidak menjual macam-macam tahu dan tempe melainkan hanya 1 macam saja tahu putih dan tempe.Dan menurut penuturan Pak sai tahu dan tempe putih yang paling diminati. Masalahnya barangnya cuma 1 jenis saja, tidak ada yang lain. ${ }^{23}$

Besarnya jumlah produksi pada disebabkan karena banyaknya permintaan konsumen dan pasar, permintaan produksi tahu tempe Pak Sai lebih meningkat dibandingkan dengan industri-industri lain, sehingga produksi tahu tempe yang dihasilkan Pak Sai mengalami peningkatan dari sebelumnya. Industri Tahu di Desa Laok Jang-Jang Kangean, memiliki pelanggan tetap dari dalamDesa Laok Jang-Jang Kangean.Industri Tahu mampu memenuhi kebutuhan permintaan konsumen di Desa Laok Jang-Jang Kangean dan sekitarnya.Pak sai sudah memiliki pelanggan tetap pembelian tahu dan tempe sekitar 6 bulana. Alasan pelanggan Pak Sai membeli tahu dan tempe yaitu dekat dengan rumah, tempatnya terjangkau, pelayanan ramah. Para pelanggan Pak Sai biasanya dilayani membeli tahu dan

\footnotetext{
${ }^{22}$ Firda, Pembeli, minggu 06 juni 2020

${ }^{23}$ Sai, penjual, 09 juni 2020
} 
tempe langsung dengan pemiliknya Pak Sai.

Sistem pembelian tempe yang biasa dilakukan Pak sai yaitu pesan dulu sebelum membelinya. Dan akad yang di gunakan adalah akad salam biasanya dilakukan dalam pembelian tempe tersebut yaitu dibayar secara cash. Dan menurut penuturan pelanggan tidak menerima pembelian dari orang lain karna pelanggan beli tahu dan tempe hanya untuk dikonsumsi sendiri dan keluarga. Menurut penuturan pelanggan yang melatarbelakangi untuk membeli produk Pak sai ini tempatnya terjangkau lalu Kelebihannya tahu dan tempe selama 3 hari masih bisa di komsumsi, tempatnya bersih dan pelayannya ramah dan untuk kekurangannya tidak ada.

Maka dapat diartikan bahwa tingkat kepuasan konsumen cukup beragam bergantung pada kualitas dan mutu produk tempe tersebut, apabila kualitas tempe yang ditawarkan oleh produsen sama atau melebihi yang diharapkan oleh konsumen maka kepuasan konsumen tersebut akan tercapai. Namun apabila kualitas tempe yang ditawarkan oleh produsen dibawah harapkan konsumen maka konsumen akan merasa tidak puas. Dengan adanya kepuasan terhadap tempe dari konsumen maka dapat menyebabkan konsumen akan melakukan pembelian ulang.

Produk tempe Pak Sai memiliki citra yang baik di kalangan konsumen tempe yang ada Di Desa Laok JangJang Kangean hal itu terbukti dari banyaknya konsumen yang lebih memilih membeli produk tempe Pak Sai daripada produk tempe lain, Di Desa Laok Jang-Jang Kangean Sumenep ini banyak yang jualan tahu tempe, tetapi Pak Sai yang paling banyak pelanggannya, itu karena dalam memproduksi tahu tempe Pak Sai benar-benar mengutamakan kualitas tahu tempe, salah satunya dengan membersihkan kulit kedelai sampai sebersih bersihnya, berbeda dengan produk tahu tempe lain yang masih banyak kulit yang tercampur dengan tempenya, hal itulah yang membuat konsumen lebih mengutamakan membeli produk tahu tempe Pak Sai daripada produk tempe lain, begitu keterangan dari Pak Sai selaku pemilik Industri tahu Tempe Di Desa Laok Jang-Jang Kangean Sumenep. ${ }^{24}$

Orang yang melakukan wirausaha harus memperhatikan beberapa hal ketika memproduksi suatu barang. Ada beberapa kaidah dalam berproduksi yang ditemukan dalam fikih ekonomi Umar bin Khattab, diantaranya pertama, aspek kaidah karena setiap aktivitas perekonomiannya mencakup wilayah ibadah, kedua aspek ilmu dimana seseorang muslim haruslah mempelajari aturan-aturan syariah yang berhubungan dengan aktivitas perekonomian agar usahanya lancar dan mendapatkan hasil yang halal, ketiga aspek amal yaitu kualitas terhadap produk yang baik yang dapat berdampak pada distribusi yang baik pula. ${ }^{25}$

Secara umum perusahaan dalam skala kecil baik usaha perseorangan maupun persekutuan seperti usaha milik Pak Sai ini memiliki daya tarik dan kelebihan tersendiri yakni Kelebihan tempekan musiman di saat angin turun, itu ikannya kurang, jadi pembuatan dalam 1 hari lebih, jadi permintakaan banyak. Ini kan sistemnnya kepulauan jadi di saat ikan banyak prosesnya berkurang, biasanya saya buat kalau angin setengah ton 1 hari, jadi kalau banyak ikan itu paling sedikitnya 2

\footnotetext{
${ }^{24}$ Sai, penjual, 09 juni 2020

${ }^{25}$ Jaribah bin Ahmad al-Haritsi, Fikih Ekonomi Umar bin Khattab, (Jeddah:Dar al-Andalus 2003), h. 64.
} 
gintal, jadi itulah kekurangan dan kelebihannya. $^{26}$

Modal dalam berdirinya suatu industri merupakan syarat yang harus dipenuhi, agar industri dapat berjalan lancar diperlukan modal yang cukup. Modal diperlukan sejak awal industri dimulai dan dipergunakan untuk membeli bahan keperluan industri, selain itu modal dapat berupa bangunan dan peralatan yang digunakan untuk tempat pengolahan tempe, namun terkadang para pengusaha mengalami kekurangan modal untuk proses produksi. Berdasrkan hasil pra survey lapangan diketahui beberapa pengusaha tempe di Desa Laok Jang-Jang Kangean mendapatkan modal usahanya dari uang pribadi atau modal sendiri, Modal dalam membuat tempe seringkali berubah ubah, karena harga dari bahan mentah yakni kedelai kerap kali mengalami kenaikan harga.

Sehingga proses penetapan harga atas masing-masing hasil penjualan tempe dan berapa keuntungan bersih yang didapatkan sangat perlu di hitungkan. Pak Sai sebagai pemilik industri tempe di Desa Laok Jang-Jang Kangean juga menjelaskan bahwa utuk peetapa da juga keuntungan bersih yang didapatkan yaitu Kalau tempe bersihnya 150 ribu perhari. Kalau tahu 1 hari 750 ribu perhari. Oleh karena itu diperlukan uraian secara rinci kepada pemilik mengenai jenis hasil penjualan tempe, harga, kualitas, kuantitas, tempat penjualan tempe bahwasanya pertama untuk kualitas yang perlu di utamakan, agar harganya standart atau biasa, kalau tempe dan tahu kalau di kangean ikut kenaikan bahan, kalau bahannyatempe dan tahu di kangean mengalami kenaikan bahanmaka harga pejualantempe dan tahu ikut naik juga.

\footnotetext{
${ }^{26}$ Sai, penjual, 10 juni 2020
}

Jadi dapat disimpulkanbahwasanya usaha Beli Tahu Tempe Di Desa Laok Jang-Jang Kangean suda dikategorikansangat baik dikarenakan konsumen yang lebih memilih membeli produk tempe Pak Sai daripada produk tempe lain, Di Desa Laok Jang-Jang Kangean sumenep ini banyak yang jualan tahu tempe, tetapi Pak Sai yang paling banyak pelanggannya, itu karena dalam memproduksi tahu tempe Pak Sai benar-benar mengutamakan kualitas tahu tempe.

Dan perilaku Pak Sai sebagai produsen dalam pengaturan proses produksi dan pemilihan barang baku pengolahan dan hasilnya sudah sesuai dengan syariat Islam. Selain itu juga Pak Sai menerapkan prinsip coutemer oriented yang diberikan kepada konsumen atas hak khiyar (meneruskan atau membatalkan transaksi) jika ada indikasi penipuan atau merasa dirugikan. Konsep khiyar ini dapat menjadi faktor untuk menguatkan posisi konsumen dimata produsen, sehingga produsen atau perusahaan manapun tidak dapat berbuat semena-mena terhadap pelanggannya.

\section{KESIMPULAN}

Berdasarkan pendekatan dari analisis tesis tersebut, peneliti menyampaikan kesimpulan sebagai berikut:

1. Konsep hukum islam dalam praktek jual beli yaitu suatu tindakan jual beli dapat dikatakan sesuai dengan akad atau sah apabila terdapat kesepakatan yang mengikat antara penjual dan pembeli (Sighat) serta konsep hukum islam atas praktik jual beli merupakan bagian dari muamalah kemudian objek yang diperjual belikan sesuai dengan syari'at yang telah diatur dalam Islam dan tidak memperjual belikan barang haram, terpenuhinya akad 
menjadi salah satu faktor sahnya jual beli yang dilakukan maksudnya adalah bahwa orang yang melakukan perjanjian jual beli atas suatu barang merupakan pilihan sah barang tersebut dan atau telah mendapat izin dari pemilik sah barang tersebut. Dengan demikian jual beli barang yang dilakukan oleh yang bukan pemilik atau berhak berdasarkan kuasa si pemilik dipandang sebagai wanprestasi.

2. Implementasi hukum ekonomi islam terhadap praktik jualbeli di Desa Laok Jang-Jang Kangean, sudah dikatagorikan sangat baik dikarenakan konsumen yang lebih memilih membeli produk tempe dengan kualitas terbaik daripada produk tempe yang lain, Desa Laok Jang-Jang Kangean sumenep terkenal akan produk tempe dengan kualitas terbaik, dari sisi implementasi hukum Ekonomi Islam juga sudah dipenuhi dimana terdapat transparasi atas produk yang dijual oleh produsen sesuai dengan kualitas yang diharapkan oleh pembeli, juga dalam proses jual belinya tidak ada unsur intimidatif serta hal-hal yang diharamkan oleh syara' serta mengedepankan aspek kemaslahatan bersama.

\section{SARAN}

Berdasarkan kesimpulan yang sudah peneliti uraikan di atas, adapun saran pada penelitian ini adalah:

1. Bagi pemilik usaha

Bahwa usaha yang digeluti harus menjadi sebuah jalan hidup dan berarti, seperti menjaga diri, berbisnis memerlukan perawatan maksimal agar tetap sehat lahir dan batin. Aspek lahir bagai mana bisa mendapatkan keuntungan. Sedangkan batin bagaimana tidak ada yang merasa dirugikan antara kedua belah pihak pembeli dan penjual atau pembuat tahu tempe sehingga semuanya merasa bahagia.

2. Bagi Akademisi dan Masyarakat

Penulis menyarankan agar digalakkan literasi terkait dengan teori manajemen dan prakteknya agar tumbuh kesadaran untuk mempelajari ilmu manajemen, jika ingin usahanya lebih maju, karena ilmu manajemen seperti pisau pembagi, mulai dari plaining, organizing, acounting, dan actuating. ke empat teori tersebut dapat mempermudah laju usaha yang bisa diharapkan kedepan, kemudian mengetur ulang tata letak dan membersihan tempat produksi serta. Melindungi konsumen atas produk yang ia produksi bagian dari aturan manajemen, dengan memberikan pelayanan maksimal dan penjagaan produk yang memadai

\section{DAFTAR PUSTAKA}

Nugroho, Riant, 2009. Public Policy Edisi Revisi. (Jakarta: Elex Media Komputindo.

Stewart,J.J, Hedge, D. M.,\& Lester, J. P, Public policy: 2008. An evolutionary approach.

Boston: Thomson Wordsworth.

Abdul Rahman Ghazaly,2010. Fiqh Muamalat, Jakarta: Kencana Prenada Media Group. M.Yahya Harahap, 1986. Segi-segi Hukum Perjanjian, Alumni, Bandung.

Sayyid Sabiq, 2006. Fiqih Sunnah, jilid 4, jakarta : pena pundi Aksara.

Gemala Dewi, 2005. Hukum Perikatan Islam diIndonesia ,Jakarta:Kencana. 
Nasrun Haroen, 2007. fiqh muamalah, Jakarta : Gaya Media Pratama.

Abu Malik Kamal, Shahih Fiqih Sunnah, Muhammad Nashirdhin al-Albani et al. 2008. jilid 5, Jakarta: Pustaka at-Tazkia.

Departemen Agama RI, 1985, h. 37

Sayyid al-Imam Muhammad Ibn Ismail al-Kahlani Al-Sanani, 1998. Subul Al-Salam Juz III, Kairo: Dar al-Kutub al-Ilmiyah.

Rachmat Syafei, 2006. Fiqih Muamalah, Bandung: CV Pustaka.

Wawancara dengan pak Sai melalui telfon pada tgl 7 agustus 2020

Yusuf Qardhawi, 1997. Peran Nilai dan Moral Dalam Perekonomian Islam, Jakarta: Robbani Press.

Hamzah Yakub, 1984,Kode Etik Dagang Menurut Islam, Bandung: Diponegoroh.

Susilo, 2004. Kelompok Kendali Mutu, Jakarta: Rajawali Pers.

Muhammad, 2007. Aspek Hukum dalam Muamalat, Yogyakarta: Graha Ilmu.

Bunyana Sholihin, 2016. Kaidah Hukum Islam dalam Tertib dan Fungsi Legislasi Hukum dan Perundang-undangan, Yogyakarta : Kreasi Total Media.

M. Lies Suprapti, 2003 Pembuatan Tempe, Yogyakarta: Kanisius.

Jaribah bin Ahmad al-Haritsi, 2003. Fikih Ekonomi Umar bin Khattab, Jeddah:Dar alAndalus. 